\title{
PEMBINAAN JAMAAH TABLIGH MELALUI PENGUATAN MODAL SOSIAL DI KOTA PALU
}

\author{
Thalib \\ FTIK IAIN Palu
}

\begin{abstract}
Fostering of Muslims in particular is a necessity. Muslims need guidance to stay on their nature, namely peace, calm, and peace (congratulations). Therefore, to maintain and preserve the atmosphere (peaceful, calm, serene), then one of the da'wah movements that has taken a role is the Tablighi Jamaat. Forms of coaching that have been done include syuro (deliberation), ta'awun (help-help). The coaching is intended to be social capital in developing Muslims. Social capital is intended as an adhesive tool for the community, because it often occurs in Islamic internal conflict communities that will affect external conflicts (among religious believers). The formation of Muslims by the followers of Tabligh has clearly brought developments to Muslims, especially in the city of Palu, this development was marked by an increase in the number of halaqah from 2 halaqah (2001) to 12 halaqah (2018), and the development has benefited the community based at the mosque.
\end{abstract}

Keywords: Fostering, Jamaah tabligh, social capital, society developing

Pembinaan terhadap umat khususnnya umat Islam merupakan suatu keniscayaan. Umat Islam memerlukan pembinaan agar tetap pada fitrahnya, yaitu damai, tenang, dan tenteram (selamat). Oleh karena itu, untuk menjaga dan melestarikan suasana itu (damai, tenang, tenteram), maka salah satu gerakan dakwah yang telah mengambil peran adalah Jamaah Tabligh. Bentuk pembinaan yang telah dilakukan diantaranya syuro (musyawarah), ta'awun (tolongmenolong). Pembinaan itu dimaksudkan untuk menjadi modal sosial (social capital) dalam mengembangkan umat Islam. Modal sosial itu dimaksudkan sebagai alat perekat bagi masyarakat, karena sering terjadi dalam masyarakat Islam konplik internal yang akan bedampak pada konplik eksternal (antarumat beragama). Pembinaan umat Islam oleh jamaah tabligh telah nyata membawa perkembangan terhadap umat Islam terutama di kota Palu, perkembangan itu ditandai dengan meningkatnya jumlah halaqah dari 2 halaqah ( tahun 2001) menjadi 12 halaqah (tahun 2018), dan perkembangan itu telah dirasakan manfaatnya oleh masyarakat yang berbasis pada masjid.

Kata Kunci: Pembinaan, Jamaah Tabligh, Modal Sosial, Pengembangan Masyarakat. 


\section{Pendahuluan}

Memasuki era milenium ketiga, telah terjadi keterbelahan kelompok secara ekstrim dalam struktur dunia Islam. Keterbelahan tersebut terbagi atas dua kelompok; Pertama, kelompok yang berada di garis moderat, yakni mereka yang dalam melihat teks agama tidak hanya tekstual, menghargai perbedaan, dan terus menggali tafsir kritis yang bermakna persamaan hak. Mereka biasanya mengusung keberagamaan di bawah payung pedamaian, kerukunan, toleransi, dan persaudaraan universal. Kedua, adalah kelompok yang menamakan diri fundamentalis. Ciri paling menonjol dari kelompok ini dalam hal keyakinan adalah penganut paham absolutisme dan tidak kenal kompromi. Dalam banyak hal, orientasi kelompok ini cenderung tidak toleran terhadap berbagai sudut pandang yang berkompetisi dan memandang realitas pluralis sebagai suatu bentuk atas kebenaran sejati.

Cap fundamental, ekstrim dan bahkan teroris seakan sangat akrab dengan komunitas orang yang memeluk Islam. Generalisasi perilaku kelompok muslim seringkali menjadi pembenaran bagi Islam sebagai agama, sehingga label-label negatif tadi selalu pantas diembelkan dengan Islam. Oleh karena keadaan demikian itu, maka sejumlah orang Barat menuduh Islam sebagai agama kekerasan. Islam diasosiasikan dengan peristiwa-peristiwa dan gerakan-gerakan yang mengancam kepentigan politik dan ekonomi Barat. 'Citra Barat tentang Islam adalah sebuah pemandangan yang rancu mengenai adat kebiasaan sosial muslim berupa pandangan hukum Islam seperti rajam, poligami dan konsep jihad'. ${ }^{1}$

Sebenarnya, ikon atau nama dengan label kekerasan terhadap Islam kalau ditelusuri sangat berlawanan dengan ajaran Islam yang sesungguhnya. Islam sangat menekankan pada umatnya untuk membangun dan meretas sebuah perdamaian di muka bumi ini. Islam memandang perdamaian yang esensial dalam kehiduapan umat manusia, karena dalam kedamaian itu terciptanya dinamikan kehidupan yang sehat, harmonis dan

\footnotetext{
${ }^{1}$ Wahyu Ilaihi. Dakwah Sebagai Solusi Perdamaian Global, kumpulan makalah Congress Proceeding Dakwah dan Pembangunan Bangsa, Surabaya: APDI, 15 sd 17 Mei 2009.
} 
humanis dalam setiap interkasi antar sesama manusia. Dalam suasana aman dan damai, manusia hidup dengan penuh ketenangan dan kegembiraan juga bisa melaksanakan kewajiban dalam bingkai perdamaian. Oleh karena itu, kedamaian merupakan hak mutlak setiap individu sesuai dengan kodratnya sebagai makhluk yang mengemban tugas sebagai pembawa amanah Allah untuk memakmurkan dunia ini. Bahkan kehadiran damai bagi kehidupan setiap makhluk merupakan sebuah tuntutan, karena dibalik ungkapan dan keadaan damai itu menyimpan keramahan, kelembutan, persaudaraan dan keadilan.

Banyak kalangan memahami perdamaian sebagai keadaan tanpa perang atau konflik. Pemahaman seperti ini merupakan contoh dari definisi negatif perdamaian.

'Secara negatif perdamaian didefinisikan sebagai situasi absennya perang dan /atau berbagai bentuk kekerasan lainnya definisi ini memang sederhana dan mudah dipahami, namun melihat realitas yang ada, banyak masyarakat tetap mengalami penderitaan akibat kekerasan yang tidak nampak dan ketidakadilan. Melihat kenyataan ini, terjadilah perluasan definisi perdamaian dan muncullah definis perdamaian positif. Definisi positif dari perdamain adalah absennya kekerasan struktural atau terciptanya keadilan sosial. ${ }^{2}$

Agama mengajarkan agar antarsesama saling mengenal atau ta'aruf, saling memahami atau tafahum, saling menghargai atau tadhammun, saling menyayangi atau tarakhhum, dan berujung agar saling tolong-menolong atau ta'awun. ${ }^{3}$ namun dalam kehidupan keagamaan masyarakat justru sebaliknya. Walaupun sesungguhnya perbedaan diciptakan setidaknya agar saling kenal mengenal, tetapi tidak jarang terjadi adalah justru saling menjauh, konflik akan menjadi pembatas dalam kehidupan bermasyarakat.

Sebenarnya, sebelum Allah menciptakan Adam, Dia telah menyampaikan rencana-Nya untuk menjadikan makhluk tersebut (bersama anak keturunannya) menjadi khalifah di bumi.

${ }^{2}$ Ibid., 6

${ }^{3}$ Imam Suprayogo. Memahami Realitas Sosial Keagamaan, (Jakarta: Kemeterian Agama RI, Badan Litbang dan Diklat Puslitbang Kehidupan Keagamaan, 2015), xi. 
Sebelum turun ke bumi, Adam bersama istrinya transit lebih dahulu di surga agar mendapat pengalaman, manis atau pahit. Sehingga dengan pengalaman tersebut, Adam memperoleh gambaran bagaimana sebenarnya kehidupan yang akan dibangun di dunia itu. Dengan kata lain, melalui transit di surga, "ia diharapkan dapat menciptakan bayang-bayang surga di bumi ini, dan bayang-banyang itulah yang dapat dinilai sebagai citacita sosial ajaran Al-Qur'an". ${ }^{4}$ di surga, ia diperingatkan:

"Hai Adam, sesungguhnya ini (Iblis) adalah musuh bagimu dan bagi istrimu. Maka, sekali-kali jangan sampai ia mengeluarkan kamu berdua dari surga yang akibatnya kamu akan bersusah payah. Sesungguhnya kamu tidak akan lapar di sini (surga), tidak pula akan telanjang, dan sesungguhnya kamu tidak akan merasa dahaga tidak akan ditimpa panas matahari (QS. Taha (20): 117-119)" 5

Demikianlah, dengan merujuk kepada ayat di atas diperoleh informasi bahwa di surga itu masyarakatnya hidup dalam suasana kedamaian, harmonis, tidak terdapat di sana suatu dosa dan tidak pula sesuatu yang tidak wajar. "Adam bersama istrinya diharapkan dengan usaha bersungguh-sungguh dapat mewujudkan bayang-bayang surga itu di permukaan bumi ini dengan berpedomankan petunjuk-petunjuk Ilahi". ${ }^{6}$

Menyangkut ajaran dari berbagai agama, apa yang biasa dibaca dari kitab suci ternyata berbeda dari apa yang terjadi dalam kehidupan nyata sehari-hari. Jarak itu kadangkala terlalu jauh. Agama mengajarkan kasih sayang, kelembutan, toleransi, dan saling menghormati, tetapi ternyata tidak jarang penganutnya saling menjauh, berperilaku kasar, dan bahkan saling menyinggung dan menyakiti dianggap hal biasa. Kasuskasus yang dimaksudkan itu tidak sulit dicarikan buktinya.

Memang tidak sedikit kenyataan ajaran agama yang berhasil diwujudkan di dalam kehidupan sehari-hari.

\footnotetext{
${ }^{4}$ M. Quraish Shihab, Membumikan Al-Qur'an, Cetakan XI, (Bandung: Mizan, 1995), 241

${ }^{5}$ Depertemen Agama RI, Al-Qur'an dan Terjemahnya, (Solo: PT. Tiga serangkai Mandiri, 2008), 320.

${ }^{6}$ Shihab, Membumikan..., 241.
} 
Mendasarkan pada ajaran agama, masyarakat menjadi hidup damai, tenteram, dan saling menjalin kasih sayang, dan tolong menolong diantara sesama. Akan tetapi, gambaran ideal itu tidak selalu bisa dilihat pada setiap waktu dan tempat. Munculnya berbagai kekerasan atas nama agama merupakan bukti bahwa apa yang terasa ideal pada kitab suci atau ajaran agama ternyata belum tentu berhasil diwujudkan dalam kehidupan sehari-hari, bahkan yang terjadi seringkali berlawanan dengan gambaran ideal itu.

Kenyataan tersebut kiranya bisa dicari akar penyebabnya. Mungkin ajaran agama yang ideal itu tidak dipahami hingga ruh atau subtansinya, melainkan baru sebatas aspek luar atau simbol-simbolnya saja, sehingga pengertian yang diperoleh tidak sampai mendalam dan menyeluruh. Selain itu juga sangat mungkin ajaran agama dimaksud, baik sengaja atau tidak, digunakan untuk kepentingan tertentu, seperti politik, ekonomi, atau kepentingan-kepentingan lainnya. Berbicara tentang agama ketika dikaitkan dengan kehidupan sosial akan selalu menjadi melebar, meluas, dan bahkan juga sebaliknya menjadi menyempit. Oleh sebab itulah antara teks dan konteks agama menjadi berbeda. Sebagai contoh sederhana, Islam mengajarkan tentang kerukunan, kebersamaan, persatuan dan umat manusia adalah umat yang satu atau ummatan wahidah, maka seharusnya umat itu tidak bercerai berai. Akan tetapi pada kenyataanya, perpecahan dan perbedaan dianggap sebagai suatu yang wajar, lazim, dan bahkan perbedaan yang nyata-nyata melahirkan kelemahan dan ketidakberdayaan umat, justru dipandang sebagai sesuatu yang menguntungkan. Hal yang demikian itu, mungkin saja agama belum dilihat dari aspek yang lebih mendasar dan subtantif, melainkan hanya dipahami dari salah satu sudut yang dangkal.

Berangkat dari kenyataan tersebut, maka perlu dilakukan suatu kajian dan sekaligus mensosialisasikannya untuk mewujudkan nilai-nilai ajaran Islam yang menyejukkan hati umat, seperti: ukhwuwah, tasamuh, syura, dan ta'awun. ${ }^{7}$ nilai-

${ }^{7}$ Zainal Abidin, Optimalisasi Peran Perguruan Tinggi Islam Sebagai Salah Satu Basis Modal Sosial Pengembangan Masyarakat, Makalah Seminar Nasional, IAIN Palu: tanggal, 23 November 2016, h. 4 
nilai islami inilah yang memungkinkan terwujudnya rasa saling percaya antar anggota masyarakat. Upaya berikutnya adalah bagaimana agar nilai-nilai tersebut wujud menjadi suatu norma, jaringan dan tumbuh rasa saling percaya yang membuat anggota masyarakat mampu bergerak bersama secara kolektif melalui 'bonding sosial capital dan bridging social capital' ${ }^{8}$. Dua modal sosial ini dimaksudkan agar mampu merekatkan anggota masyarakat sehingga mendorong orang untuk saling mendukung, dan memungkinkan terciptanya hubungan antar berbagai kelompok sosial, sehingga memiliki akses sumber daya satu sama lain.

Kenyataan di lapangan atau di masyarakat bahwa telah ada gerakan dakwak yang memperaktekkan atau mengamalkan hal tersebut, seperti: ukhuwah, tasamuh, syura, dan ta'awun, namun bagaimana cara dan bentuknya masih perlu dilakukan pengkajian untuk mendapatkan penjelasan dan kejelasan apa dasar dan motifasinya melakukan hal tersebut. Gerakan dakwah dimaksud adalah Jamaah Tabligh yang telah melakukan penguatan modal sosial keagamaan bagi pengembangan masyarakat Islam dengan pembinaan melalui dakwah yang sampai saat ini telah meliputi 12 (dua belas) halaqah di Kota Palu, yaitu: (1) halaqah Ulujadi (2) halaqah Palu Barat 1, (3) halaqah Palu Barat 2, (4) halaqah Tatanga 1, (5) halaqah Tatanga 2, (6) halaqah Palu Selatan 1, (7) halaqah Palu Selatan 2, (8) halaqah Mantikulore 1, (9) halaqah Mantikulore 2, (10) halaqah Mantikulore 3, (11) halaqah Tawaeli, dan (12) halaqah Palu Utara

Gerakan pembinaan Jamaah Tabligh secara umum dijelaskan bahwa mereka telah melakukan bentuk pembinaan dengan penguatan modal sosial melalui syura atau musyawarah. Musyawarah dimaksud seperti: musyawarah mingguan, bulanan, dan jord bulanan halaqah, musyawarah kodya (kota Madya) Palu setiap 2 bulan sekali. Baik musyawarah maupun jord, ini dimaksudkan sebagai wahana pembinaan, evaluasi dan tindaklajut. Ta'awun atau tolong-

${ }^{8}$ Ibid, h. 2 
menolong juga telah diperaktekkan atau diamalkan dalam dakwah jamaah tabligh, seperti ta'awun dalam khidmat (menyiapkan makanan, bantuan materi) bagi peserta musyawarah halaqah, setiap tamu halaqah, setiap keluarga yang ditingalkan khuruj fii sabilillah oleh suami-suami mereka, dan setiap jamaah gerak yang kehabisan dalam perjalanan. Tentang ukhuwah islamiyah atau persaudaraan sesama muslim sangat nampak dalam kehidupan sehari-hari, mereka saling makan berjamaah, berangkulan walaupun baru bertemu (jamaah baru datang), hal ini nampak baik jamaah dalam negeri maupun dari luar negeri. Secara umum hal inilah yang sering nampak, akan tetapi bagaimana metode dan tehniknya, apa dasar dan motivasinya, dan bagaimana output dan folow upnya, masih perlu kajian lebih lanjut. Dalam konteks inilah peneliti tertarik untuk melakukan telaah dalam bentuk penelitian terhadap bentuk pembinaan melalui penguatan modal sosial jamaah tabligh di Kota Palu.

Pendekatan yang dilakukan dalam penelitian ini adalah kualitatif naturalistik, yaitu penelitian yang mengarahkan formatnya pada keaslian data, kealamiahan ungkap subyek (realistik) dan bersifat induktif. ${ }^{9}$ Dengan tujuan menguraikan dan memberikan penjelasan (eksplanasi), memberikan pemahaman yang bersifat menyeluruh (komprehensif) dan mendalam (in-deph) tentang fenomena-fenomena sosial yang menjadi objek studi.

\section{Metodologi Penelitian}

Penelitian ini dilakukan melalui komunitas objek (community studies), yakni penelitian yang memfokuskan pada masyarakat desa dan kota pada 12 halaqah, yaitu: halaqah Ulujadi, Palu Barat 1, Palu Barat 2, Tatanga 1, Tatanga 2, Mantikulore1, Mantikulore 2, Mantikulore 3, Palu Selatan 1, Palu Selatan 2, Palu Utara, dan Tawaeli. Oleh karena itu, maka penelitian ini menggunakan pendekatan sosio-antropologis,

${ }^{9}$ Neong Muhajir, Metodologi Penelitian Kualitatif, (Yogyakarta: Rake Sarasin 2000), h. 108. 
yakni penelitian yang penekanannya pada studi manusia dan masyarakat, interkasi dan fakta-fakta sosial dari keduanya, sehingga peneliti dapat menginterpretasi dan memahami pengalaman individu maupun kelompok yang hidup dalam satu jalinan keluarga, kelompok agama sebagai pelaku sosial. Pengamatan dilakukan melalui fenomena empirik yaitu dengan mengumpulkan sebanyak mungkin informasi dari masyarakat mengenai apa yang dilihat, dirasakan, dilakukan, didefinisikan dan dipahami oleh masyarakat.

Dengan pendekatan ini, peneliti berusaha memahami dan mengungkapkan sikap perilaku massa keagamaan dalam merelisasikan ide jamaah tabligh melalui pelaksanaan program syuro, ta'awun dan ukhuwah islamiyah. Pendekatan ini memungkinkan peneliti mendapat data mengenai hubungan program jamaah tabligh dari setiap halaqah sampai ke markas (Masjid Awwabin, Jl. Mangga) secara intensif dan mendalam.

Data dan Sumber Data dalam penelitian ini adalah semua subyek, lokasi, dokumen, aktivitas dan peristiwa (musyawarah halaqah dan jord halaqah) yang mempunyai ketertarikan dengan fokus penelitian ini merupakan sumber data penelitian ini. Sumber data yang dipakai dalam penelitian ini dibagi menjadi dua, yaitu data primer dan data skunder. Data primer berasal dari data yang langsung diambil melalui kegiatan lapangan penelitian seperti observasi keadaan lapangan baik melalui musyawarah halaqah, dan jord halaqah, di setiap halaqah dalam Kota Palu, dan wawancara mendalam (in depth interview). Data sekunder, dari literatur buku dan dokumentasi-dokumentasi hasil musyawakah dan jord, tentang hubungan pelaksanaan program jamaah tabligh dalam pembangunan modal sosial bagi pengembangan masyarakat Islam di Kota Palu.

Metode pengumpulan data penelitian ini, berupa participan observation dan indepth interview sebagai metode 
pengumpulan data utama. ${ }^{10}$ Participan observation subjek dan objek penilitian, hal ini untuk melihat perilaku masyarakat dalam keadaan alami dan mencermati dinamika kehidupan secara langsung. Hasilnya berbentuk field note yang akan dianalisis dan diinterpretasikan. Indept interview (wawancara mendalam), untuk mengungkap data yang berkaitan dengan masalah yang diteliti, wawancara mendalam menjadi pilihan utama yang dilakukan kepada penanggung jawab halaqah, penangung jawab data halaqah, dan paisalat markas kota Palu. Hasil wawancara ini dalam bentuk interview transkrip.

Data analisis dengan metode analisis kualitatif. Sesuai saran dari Miles \& Hubermen, ${ }^{11}$ yang meliputi tiga tahapan yaitu: pertama reduksi data untuk menajamkan, menggolongkan, mengarahkan, menyederhanakan, dan mengorganisasikan data, kedua, penyajian data dan informasi dan diperoleh sebagai dasar pengambilan kesimpulan berupa (1) teks naratif untuk menggambarkan pandangan informan, (2) tabel/bagan untuk menggambarkan data-data informan, ketiga penarikan kesimpulan berdasarkan reduksi dan penyajian data baik dalam bentuk narasi maupun tabulasi, sehingga dapat memberikan arti penting temuan penelitian.

\section{Perkembangan Dakwah Jama'ah Tabligh Di Kota Palu}

Gerakan dakwah jamaah tabligh merupakan gerakan dakwah yang cukup dinamis. Gerakan dakwah ini berjalan terus-menerus dan berkesinambungan, hal ini dapat dilihat dengan berkembangnya wilayah tempat gerakan dakwah ini hampir diseluruh kabupaten di propinsi sulawesi tengah jamaah ini telah eksis.

Gerakan dakwah ini memang sangat antusias atau bersemangat walaupun dalam keadaan kontopersi ditengah-

\footnotetext{
${ }^{10}$ Robert C. Bogsan \& Sari Knoop Biklen, Quality Research for Education: An Introduction to Theory and Methods (Boston: Allyn and Bacon, tt), 2. Lihat juga Norman K.Dezim Yvonna S.Lincoln, Handbook of Qualitative Resarch (California sage Publication, 1994), 1-7.

${ }^{11}$ Miles, M. B Miles and A.M Hubermen, Analisis Data Kualitatif, terjemahan. Tjetjep \& Rohadi, (Jakarta: UI Press, 19992), 16-19.
} 
tengah masyarakat, namun perkembangan dakwah tidaklah surut dengan tantangan yang ada khususnya tantangan dalam masyarakat di kota Palu. Bukti dari perkembangan jamaa tabligh di kota Palu ialah dengan berkembangnya jumlah halaqah yang sampai saat ini talah mencapai 12 (dua belas) halaqah.

Perkembangan dakwah jamaah tabligh dari tahun ketahun mengalami perkembangan, hal ini terbukti bahwa sejak 2000 itu baru 2 (dua) halaqah, yaitu: halaqah Palu Timur dan halaqah Palu Barat. Dua tahun kemudian (tepatnya tahun 2002) menjadi (empat) halaqah, yaitu: halaqah Palu Timur, Palu Barat, Palu Utara, dan Palu Selatan.

Usaha dan gerakan dakwah jamaah tabligh terus berjalan seiring dengan berjalannya waktu. Artinya, pekerja dakwah terus bekerja dan berusaha mengembangkan walaupun ada tantangan dari masyarakat, tetapi dengan pendekatan persuasif semua bisa terselesaikan dengan baik. Disamping itu, juga berkat ibadah dan do'a disertai dengan niat yang tulus untuk pengembangan usaha Rasulullah Saw., mengenalkan, mendekatkan, dan mengajak manusia taat kepada Allah Swt., dengan niatan seperti itu, maka pekerja dakwah semakin antusias sehingga gerakan dakwah juga semakin mengalami perkembangan.

Perkembangan itu ditandai dengan semakin banyaknya masyarakat yang memberi respon positif dan ikut mengambil bahagian dalam usaha dakwah. Artinya, orang yang ikut dalam usaha dakwah mengambil manfaat dari segi ibadah (merasakan ketenangan jiwa, ketenangan hidup) baik secara pribadi maupun keluarga. Dengan adanya manfaat seperti itu, maka secara individu dan masyarakat turut memberikan manfaat juga terhadap gerakan dan usaha dakwah sehingga usaha dakwah mengalami kemajuan.

Berdasarkan uraian dan pengamatan dari semua halaqah yang ada di Kota Palu, menunjukkan bahwa pusat halaqah dakwah jamaah tabligh berada disetiap kecamatan atau kelurahan. Dengan demikan bahwa sejak tahun 2012 
halaqah dakwah telah berjumlah 12 (dua belas) halaqah. Dapat dilihat pada tabel di bawah ini:

Tabel 1

Posisi Halaqah Dakwah Jamaah Tabligh di Kota Palu

\begin{tabular}{|c|c|c|c|}
\hline NO & HALAQAH & KECAMATAN & INDUK HALAQAH/MASJID \\
\hline 1 & $\begin{array}{l}\text { palu barat } 1 \\
\text { (pb 1) }\end{array}$ & $\begin{array}{l}\text { kecamatan palu } \\
\text { barat }\end{array}$ & $\begin{array}{l}\text { masjid al-muhajirin (impres } \\
\text { manonda/jl. kunduri) }\end{array}$ \\
\hline 2 & $\begin{array}{l}\text { palu barat } 2 \\
\text { (pb 2) }\end{array}$ & $\begin{array}{l}\text { kecamatan palu } \\
\text { barat }\end{array}$ & $\begin{array}{l}\text { masjid jami (kampung } \\
\text { baru/jl. wahid hasyim) }\end{array}$ \\
\hline 3 & ulu jadi & $\begin{array}{l}\text { kecamatan ulu } \\
\text { jadi }\end{array}$ & $\begin{array}{l}\text { masjid al-mujahidin (silae/jl. } \\
\text { diponegoro) }\end{array}$ \\
\hline 4 & tatanga 1 & $\begin{array}{l}\text { kecamatan } \\
\text { tatanga }\end{array}$ & at-tayyibah (pengawu/jl. ) \\
\hline 5 & tatanga 2 & $\begin{array}{l}\text { kecamatan } \\
\text { tatanga }\end{array}$ & $\begin{array}{l}\text { masjid nurul qalby (jl. } \\
\text { ogotion) }\end{array}$ \\
\hline 6 & $\begin{array}{l}\text { palu selatan } \\
1\end{array}$ & $\begin{array}{l}\text { kecamatan pali } \\
\text { selatan }\end{array}$ & $\begin{array}{l}\text { masjid darussalam } \\
\text { (masomba/jl. emi saelan) }\end{array}$ \\
\hline 7 & $\begin{array}{l}\text { palu selatan } \\
2\end{array}$ & $\begin{array}{l}\text { kecamatan palu } \\
\text { selatan }\end{array}$ & $\begin{array}{l}\text { masjid an-nur (kompleks } \\
\text { kehutanan/ jl. dewi sartika } \\
\text { no.3) }\end{array}$ \\
\hline 8 & $\begin{array}{l}\text { mantiku-lore } \\
1\end{array}$ & $\begin{array}{l}\text { kecamatan } \\
\text { mantikulore }\end{array}$ & $\begin{array}{l}\text { masjid ar-rahman (tondo/jl. } \\
\text { soekarno hatta) }\end{array}$ \\
\hline 9 & $\begin{array}{l}\text { mantiku-lore } \\
2\end{array}$ & $\begin{array}{l}\text { kecamatan } \\
\text { mantikulore }\end{array}$ & $\begin{array}{l}\text { masjid al-ikhlas } \\
\text { (mantikulore/ jl. } \\
\text { samratulangi/ Irg. kapista) }\end{array}$ \\
\hline 10 & $\begin{array}{l}\text { mantiku-lore } \\
3\end{array}$ & $\begin{array}{l}\text { kecamatan } \\
\text { mantikulore }\end{array}$ & masjid al-istiqlal (jl. juanda) \\
\hline 11 & tawaeli & $\begin{array}{l}\text { kecamatan } \\
\text { tawaeli }\end{array}$ & $\begin{array}{l}\text { masjid an-nur (baiya raya/jl. } \\
\text { trans pantoloan). }\end{array}$ \\
\hline 12 & palu utara & $\begin{array}{l}\text { kecamatan palu } \\
\text { utara }\end{array}$ & $\begin{array}{l}\text { masjid bahrul ulum } \\
\text { (mamboro perikanan/jl. } \\
\text { tanjung bulu). }\end{array}$ \\
\hline
\end{tabular}

Sumber Data: Masjid Al-Awwabin Markas Kota Palu Sul-Teng Agustus 2018 


\begin{abstract}
Pengamatan menunjukkan bahwa kedua belas halaqah diatas semuanya aktif dalam musyawarah halaqah pekanan/mingguan sehingga penelitian tidak banyak terjadi masalah jamaah di halaqah. Artinya, masalah-masalah yang terjadi disetiap mahalah dapat dipecahkan dan diatasi dengan baik melalui musyawarah halaqah.
\end{abstract}

Bentuk-bentuk Syuro Jamaah Tabligh Dalam Penguatan Modal Sosial untuk Mengembangkan Masyarakat Islam di Kota Palu.

Syuro (musyawarah) dalam gerakan dan usaha dakwah jamaah tabligh merupakan suatu keharusan. Artinya, semua tindakan yang akan dilakukan berkaitan dengan dakwah harus melalui proses musyawarah. Proses awal musyawarah dimulai dari musyawarah mahalah, kemudian dari hasil musyawarah disetiap mahalah akan di musyawarahkan lagi pada musyawarah halaqah.

Musyawarah halaqah merupakan musyawarah tertinggi pada tingkat mahalah. Artinya, pada musyawarah halaqah semua mahalah ikut musyawarah, untuk menyampaikan hal-hal yang berkaitan dengan masalah dakwah dan telah dimusyawarahkan di mahalah.

Pengamatan menunjukkan bahwa semua hal atau masalah ataupun harapan-harapan dalam setiap mahalah akan dibicarakan pada Musyawarah halaqah ini menghadirkan semua mahalah dan harapan-harapan apalagi dibicarakan bersama secara terbuka pada musyawarah halaqah tersebut. Artinya, semua harapan-harapan dari setiap masalah akan tertuangkan dan dibicarakan dan diputuskan melalui musyawarah halaqah.

Bagaimana proses musyawarah halaqah akan $\mathrm{du}$ uraikan seperti berikut ini: langkah pertama, memilih pemimpin musyawarah. Pemimpin musyawarah ini akan memimpin musyawarah halaqah pada saat itu.

Langkah kedua, pemimpin musyawarah menunjuk salah seorang dari jamaah yang hadir yang akan memberikan sihin. Sihin ini artinya memberikan semangat dan menyatukan pikir, 
yaitu semua peserta musyawarah memfokuskan perhatian dan pikiran atau konsekuensi penuh pada musyawarah.

Langkah ketiga, absensi. Artinya mengabsen peserta atau mahalah yang hadir, dan sekaligus menanyakan manakala ada mahalah yang tidak hadir tentang ketidakhadirannya, dan ditunjuk mahalah yang berdekatan untuk menghadirkannya pada musyawarah minggu berikutnya.

Langkah keempat, itiqali. Itiqali adalah membicarakan jamaah yang akan keluar fisabilillah: 4 bulan negeri jauh, 4 bulan IPB (India, Pakistan, Banglades), 4 bulan jalan kaki, dan 4 bulan biasa. Demikian juga jamaah 40 hari: 40 hari jalan kaki, dan 40 hari biasa. Kemudian jamaah masturat: 2 bulan IP (India dan Pakistan), 40 hari luar negeri, dan dalam negeri. Kemudian 15 hari atau 10 hari, dan 3 hari masturat. Kemudian jamaah pelajar: 4 bulan setelah tamat belajar (setelah sarjana), 40 hari atau 3 hari.

Langkah kelima, nusroh keluarga yang ditinggal. Jamaah rijal yang telah keluar fisabilillah, berarti mereka meninggalkan istri dan anak-anaknya, walaupun sebelumnya mereka telah dipersiapkan (ditapakut) oleh halaqah maupun markas. Hal ini dilakukan untuk menjaga hal-hal atau masalah yang memerlukan bantuan, sehingga keluarga yang ditinggal khuruj tidak merasa kesulitan saat ditinggal oleh kepala keluarga atau suami mereka, juka ada kesulitan atau masalah akan ditangani bersama oleh orang-orang halaqah.

Pengamatan menunjukkan bahwa musyawarah halaqah dilakukan setelah shalat magrib dan selesai menjelang shalat isya, dan bahkan berlanjut setelah shalat isya jika ada hal atau msalah yang belum tuntas dibicarakan waktu musyawarah sebelumnya.

Pengamatan juga menunjukkan bahwa pada musyawarah setiap halaqah terkadang terdapat perbedaan dalam menerapkan langkah-langkah dalam musyawarah. Perbedaan langkah tersebut tergantung banyaknya agenda yanag akan dibicarakan atau sesuai kebijakan pemimpin musyawarah yang terpilih memimpin musyawarah. Hal ini 
diketahui berdasarkan keterangan dari informan dari setiap halaqah. Salah satu informan menjelaskan: bahwa proses musyawarah terkadang ada kebijakkan dari pimpinan musyawarah, seperti "pemilihan amir musyawarah, sihin musyawarah, kargosari, dan usul-usul"12

Dari hasil wawancara di atas dapat di pahami bahwa amir halaqah Ulujadi sesekali mengambil kebijakan guna mempersingkat langkah-langkah yang di tempuh dalam musyawarah. Mempersingkat langkah ini sebagai kebijakan untuk mempercepat atau mempersingkat waktu musyawarah langsung pada fokus isi musyawarah disesuaikan dengan kondisi waktu yang tersedia, atau mungkin juga ada keperluan lain, seperti ditempat itu ada undangan kedukaan atau tahlilan ataupun baca do'a lainnya. Dengan demikian kebijakan dalam musyawarah sangat dipengaruhi oleh keadaan atau hajat masyarakat setempat di mana musyawarah itu diadakan, karena memang dakwah ini adalah dari masyarakat dan untuk masyarakat. Oleh karena itu, kebijakan dapat saja dilakukan karena mempertimbangkan kepentingan atau kebutuhan masyarakat khususnya kebutuhan ibadah.

Bagaimana proses musyawarah pada halaqah lainnya, seperti pada halaqah Tatanga. Halaqah ini melakukan musyawarah halaqah melalui tahapan musyawarah seperti berikut: tahap pertamma, memilih amir musyawarah. Pemilihan amir musyawarah karena ada dua atau tiga orang penanggungjawab halaqah, maka dipilih salah satunya untuk menjadi amir musyawarah pada saat musyawarah mingguan halaqah.

Tahap kedua, sihin musyawarah. Setelah amir terpilih, maka amir menunjuk salah seorang dari jamaah untuk memberikan sihin agar pikiran jamaah semuanya tertuju atau fokus pada musyawarah atau penyatuan pikir.

Tahap ketiga, kargosari setiap mahalah. Kargosari ini dimaksudkan untuk menyampaikan keadaan mahalah berkaitan

12 Ust. Ujang Anshari. Penaggungjawab Halaqah Ulujadi, wawancara, tanggal, 27 Maret 2018, di Masjid Mujahidin. 
dengan jamaah intiqali dan nusroh jamaah dan keluarga yang ditinggal.

Tahap keempat, jamaah intiqoli. Pada tahap ini adalah menyampaikan bagaimana kesiapan maupun jamaah yanag akan khuruj fi sabilillah. Baik dari jamaah setiap mahalah maupun jamaah rangka yang telah dirancang sebelumnya dari setiap mahalah dan setelah disatukan jamaahnya dengan mahalah lain yang memiliki niat yang sama, misslnya: jamaah 4 bulan jalan kaki, jamaah 4 bulan negeri jauh, jamaah 4 bulan IPB (India, Pakistan, Banglades), jamaah jalan kaki 40 hari, jamaah 40 hari biasa. Selain jamaah rijal/laki-laki, ada juga jamaah masturat (jamaah suami isteri), seperti jamaah masturat 2 bulan IP (India, Pakistan), 40 hari masturat, 15 hari masturat dan 3 hari masturat.

Tahap kelima, nusroh keluarga yang ditinggal. Dalam hal nusroh keluarga ini adalah istri dan anak yang ditinggal khuruj fii sabilillah oleh suaminya.tentang nusroh ini ada tertib tersendiri, karena yang dinusroh adalah istri yang ditinggalkan fiisabilillah, maka yang nusroh adalah istri jamaah yang diputuskan dalam musyawarah.

Hasil dari musyawarah tersebut diatas pada tahap selanjutnya dievaluasi para jamaah secara bersama-sama. Setiap sesuatu yang dilakukan selalu mengharapkan ada hasil yang di capai. Oleh karena itu, setiap musyawarah halaqah ada hasil yang di capai, seperti: intiqoli, terbentuknya jamaah 4 bulan jalan kaki bulan Juni 2018, 40 hari biasa bulan April (13 April 2018), dan 40 hari perjalanan 1 jamaah target libur (keluar masa libur). Jamaah 3 rijal.

Jamaah 4 (empat) bulan rijal bulan Juni 2018. Jamaahnya adalah sebanyak 9 (sembilan) amaah 9 (sembilan) orang tersebut, yaitu: “(1) $\mathrm{Pa}^{\prime}$ Udin, (2) $\mathrm{Pa}^{\prime}$ Parman, (3) $\mathrm{Pa}$ ' Arafat, (4) Ust. Rahmat, (5) Pa' Hatta, (6) Pa' Ibnu Yudi, (7) Pa' Husen, (8) Pa' Ilham, dan (9) Mas Unzzen."13 Selanjutnya, jamaah 3 (tiga) hari nizab rijal, yaitu gabungan tiga masjid:

${ }^{13}$ Hasil musyawarah halaqah, Masjid At-Tayyibah (sentral halaqah) Pengawu, tanggal , 27 Maret, 2018. 
masjid Al-Ashar, masjid Nur-Hasanah, dan masjid Asy-Syakirin. Amir jamaah Pa' Umar, petugas bayan hidayah Maulana Didit, rute jamaah masjid Asy-Syakirin, waktu bayan hidayah jam 06:00 (ba'da subuh). ${ }^{14}$ Selanjutnya takaza markaz, yaitu: sosialisasi hasil musyawarah nasional, dan korban (pembayaran) per-halaqah Rp. 100.000,- (seratus ribu rupiah) untuk keperluan sosialisasi karena orang-orang daerah/orang kabupaten diundang: seperti kabupaten Parigi, kabupaten Tolitoli, Buol, Luwuk, Bangkep, dan lain-lain". ${ }^{15}$

Hasil musyawarah berikutnya adalah yang berkhidmat dimarkas dan di halaqah. Khidmat markas yaitu mahalah "baitussalam, Assyakirin, dan Al-Ashar. Sedangkan yang berkhidmat di halaqah, yaitu: Attayibah, Al-Hidayah, dan NurHasanah. Tentang berkhidmat ini informan menjelaskan:

"Berkhidmat di markas Masjid Al-Awwabin Jl. Mangga setiap malam jum'at atau pagi setiap setiap hari untuk menjamu tamu yang datang dari daerah-daerah atau kabupaten sesulawesi tengah yang biasanya sampai 10-30 orang setiap hari. Khidmat halaqah ini dimaksudkan untuk menghendel khidmat (makan-minum) saat musyawarah halaqah setiap hari selasa malam, mulai ba'da magrib sampai isya. Musyawarah terkadang banyak pembahasan sehingga musyawarah terkadang ba'da isya masih berlanjut sehingga dengan demikian perlu demikian perlu khidmat malam". ${ }^{16}$

Dari informasi di atas dapat dipahami bahwa khidmat (makan-minum) dimaksudkan untuk memberikan perhatian para jamaah agar senantiasa intensif mengikuti musyawarah halaqah karena diberikan khidmat setelah musyawarah, halaqah. Artinya, halaqah juga memperhatikan antara pekerjaan dan khidmat (makan-minum) harus sehigga memberikan kesegaran setelah melakukan musyawarah.

\footnotetext{
${ }^{14}$ Hasil musyawarah halaqah, Masjid At-Tayyibah Pengawu (sentral halaqah), tanggal, 27 Maret 2018.

${ }^{15}$ Hasil musyawarah halaqah, Masjid At-Tayyibah Pengawu (sentral halaqah) tanggal , 27 Maret 2018.

${ }^{16}$ Ust. Arifin. Amir halaqah Tatanga 1, wawancara, Masjid AtTayyibah Pengawu (sentral halaqah), tanggal, 27 Maret 2018.
} 
Pengamatan menunjukkan bahwa pada saat musyawarah halaqah ada petugas yang ditunjuk untuk menyiapkan khidmat, sehingga setelah musyawarah biasanya langsung disuguhkan makan-minum dan jamaah merasa nyaman setelah musyawarah berakhir. Dengan makan-minum setelah bermusyawarah berarti mencairkan suasana ketegangan pikiran saat musyawarah, dan ini "salah satu amalan dai empat amalan yang harus diperbanyak yaitu: dakwah ilallah, ta'lim wata'lum, zikir wal ibadah dan khidmat". ${ }^{17}$

Dari informasi di atas dapat dipahami bahwa khidmat (makan-minum) dimaksudkan untuk memberikan perhatian para jamaah agar senantiasa intensif mengikuti musyawarah halaqah karena diberikan khidmat setelah musyawarah, halaqah. Artinya, halaqah juga memperhatikan antara pekerjaan dan khidmat (makan-minum) harus sehigga memberikan kesegaran setelah melakukan musyawarah.

Pengamatan menunjukkan bahwa pada saat musyawarah halaqah ada petugas yang ditunjuk untuk menyiapkan khidmat, sehingga setelah musyawarah biasanya langsung disuguhkan makan-minum dan jamaah merasa nyaman setelah musyawarah berakhir. Dengan makan-minum setelah bermusyawarah berarti mencairkan suasana ketegangan pikiran saat musyawarah, dan ini "salah satu amalan dai empat amalan yang harus diperbanyak yaitu: dakwah ilallah, ta'lim wata'lum, zikir wal ibadah dan khidmat". ${ }^{18}$

Dari informasi diatas dapat di pahami bahwa kegiatan di masjid selalu memperhatikan empat amalan tersebut di atas. Oleh karena itu, sempurnanya amalan di masjid harus ada khidmat, maka dalam kegiatan musyawarah selalu ada acara khidmat (makan-minum) setelah musyawarah selesai.

\footnotetext{
${ }^{17}$ Ust. Arifin. Amir halaqah Tatanga 1, wawancara, Masjid AlAwwabin (markas) Palu, tanggal 28 Maret 2018.

${ }^{18}$ Ust. Arifin. Amir halaqah Tatanga 1, wawancara, Masjid AlAwwabin (markas) Palu, tanggal 28 Maret 2018.
} 
Pengamatan menunjukkan bahwa hampir semua
halaqah melakukan amalan khidmat ini setelah mereka mengadakan musyawarah, apakah itu musyawarah mingguan halaqah, musyawarah bulanan halaqah atau musyawarah dua bulanan kodya Palu. Pertanyaan kemudian siapa yang menanggung biaya khidmat itu? Itu biasanya dari musyawarah harian mahalah siapa yang berkenan atau yang siap berkhidmat pada malam musyawarah halaqah atau mungkin juga patungan satu mahalah sehingga terasa ringan. Hal ini berdasarkan informasi dari salah seorang amir halaqah, beliau mengatakan bahwa "khidmat setiap malam musyawarah halaqah biasanya kita satu mahalah itu patungan (kumpul uang sama-sama), dan kadang juga ada diantara teman yang siap secara pribadi atau mungkin karena ada hujatan:. ${ }^{19}$

Dari hasil musyawarah halaqah selalu ada outputnya, seperti halnya intiqali jamaah baik empat bulan, empat puluh hari, dan demikian juga masturat dua bulan IP (India dan Pakistan), empat puluh hari dan lima belas hari. Jamaah yang akan diberangkatkan dipersiapkan jauh-jauh hari dengan tafakut yang sehat. Artinya, bahwa jamaah yang diberangkatkan dengan menggunakan harta dan diri, maka harus dipersiapkan dengan matang tentang biaya yang akan dibawa khuruj fii sabilillah, dan demikian juga biaya yang ditinggalkan untuk keluarganya, apalagi khuruj fii sabilillah dengan masa panjang 4 bulan (empat bulan).

Pengamatan menunjukkan bahwa jamaah yang dikeluarkan fii sabilillah dengan masa panjang 4 (empat) bulan, harus ditafakud (dipersiapkan dengan teliti) dengan tim tafakud markas. Maksud tim tafakud ini untuk mempersiapkan jamaah yang sehat secara amaliah maupun dengan amwal (persiapan harta/uang). Dalam hal ini, harta atau uang dimaksudkan untuk persiapan keluar dan yang ditinggalkan untuk keluarga (istri dan anak). Dalam konteks ini, informan menjelaskan bahwa

${ }^{19}$ H. Anwar. Penanggung jawab halaqah Palu Barat 2, wawancara, Masjid Jami Kamping Baru (sentral halaqah) Palu Barat 2, tanggal 01 Mei 2018. 
"jamaah yang akan khuruj fii sabilillah ditafakud oleh tim tafakud dari markas dengan maksud agar tidak meninggalkan masalah bagi keluarga dan jamaah setelah berangkat fii sabilillah". ${ }^{20}$

Dari informasi di atas dipahami bahwa tafakud dilaksanakan agar jamaah yang akan berangkat tidak bermasalah baik keluarga yang ditinggalkan maupun dan jamaah setelah diberangkatkan. Kalaupun ada jamaah kadang terjadi masalah itu disebabkan orang yang joss (bersemangat tinggi tapi tidak tertib) sehingga waktu ditafakud menyembunyikan keadaan sebenarnya atau tidak transparan.

Pollow up dari hasil musyawarah adalah pengiriman atau pengeluaran jamaah. Namun sebelumnya melalui proses: pertama, membuat jamaah rangka (4 bulan IPB, 40 hari dan lain-lain), kedua, memilih amir bayangan, ketiga, membentuk tim usuli, keempat, saling undang makan bersama. Dalam konteks ini, informan menjelaskan bahwa tindak lanjut dari hasil musyawarah adalah "membentuk jamaah rangka yang terdiri atas 6 (enam) sampai 10 (sepuluh) orang, kemudianjamaah rangka yang sudah terbentuk tersebut dipilih amir bayangannya, setelah itu dibentuk tim usuli, dan saling mengandung untuk makan bersama"21

Berdasarkan pengamatan pada musyawarah halaqah khususnya halaqah Palu Barat 2 bahwa dua bulan terakhir ini musyawarah di fokuskan pada pengeluaran jamaah saat ijtima'i sulawesi tengah pada tanggal, 20, 21, dan 22 Juli 2018. Pada saat ini takaza markas memberi target setiap halaqah mengeluarkan jamaah 4 (empat) bulan 1 jamaah, 40 hari masing-masing 2 jamaah.

Berdasarkan takaza markas tersebut, maka dari halaqah Palu Barat 2 telah menyiapkan jamaah rangka 4 (empat) bulan

20 Abd. Rahman Herto. Penanggung jawab halaqah Palu Barat 2, wawancara, Masjid Jami Kampung Baru (sentral halaqah) Palu Barat 2, tanggal 08 Mei 2018.

${ }^{21}$ Aco. Amir halaqah Palu Barat 1 sekaligus tim taskil markas, wawancara, Masjid Al-Muhajirin (sentral halaqah Palu Barat), tanggal 08 Mei 2018. 
satu jamaah dan 40 hari 2 jamaah, dan "diharapkan bahan buku dari jamaah tersebut dari masing-masing mahalah menyiapkan minimal 1 orang, dan sudah dipilih amir bayangannya serta telah dipilih tim usuli halaqah untuk mempersiapkan jamaah tersebut, dan difiralkan terus sampai jamaah tersebut diberangkatkan". 22

Persiapan halaqah sebagai output dari hasil musyawarah adalah pengeluaran jamaah. Informasi dari halaqah Tatanga menjelaskan bahwa dalam rangka memsukseskan ijtima'i sulawesi tentah, maka dari markas Masjid Al-Awwabin jalan Mangga memberikan takaza setiap halaqah khusus dari halaqah Tatanga 2 telah menyiapkan "jamaah 4 (empat) bulan 1 jamaah, dan jamaah 40 hari, dan diberi tugas untuk mengusuli jamaah rangka yang telah dipersiapkan, dan sampai saat ini jamaah rangka telah siap 60 $\% " .23$

Dari uraian di atas, dapat disimpulkan bahwa output setiap musyawarah adalah pengeluaran jamaah. Pengeluaran dimaksudkan sebagai upaya mewujudkan tanggungjawab sosial atau tanggung jawab atas ummat setelah tanggung jawab individu/keluarga.

Tanggung jawab sosial ini amat penting karena keadaan masyarakat akan berpengaruh terhadap individu/keluarga, bagaimana baiknya pendidikan dalam keluarga jika tidak disertai dengan baiknya pendidikan dimasyarakat,, maka lambat laun keluarga akan terpengaruh dengan yang ada dimasyarakat. Dalam konteks ini, informan menjelaskan bahwa salah satu tujuan musyawarah dan output dalam setiap musyawarah adalah "agar ada pikir tanggungjawab atas agama baik pada diri sendiri, keluarga, dan masyarakat bahkan ummat seluruh alam". 24

${ }^{22}$ H. Anwar. Amir halaqah Palu Barat 2, wawancara, di Masjid Jami Kampung Baru (sentral halaqah), tanggal 12 Juni 2018.

${ }^{23}$ Mas Eko. Amir halaqah Tatanga 2, wawancara, di Masjid AAwwabin (markas Jl. Mangga) tanggal, 07 Juni 2018.

${ }^{24}$ Abd. Rahim. Faisalat Markas/penanggungjawab dakwah Profinsi Sulteng, wawancara, Masjid Al-Awwabin, tanggal, 05 Mei 2018. 


\section{Penutup}

Modal sosial sebagai wujud adanya tanggung jawab sosial. Tanggung jawab sosial ini akan wujud jika dalam suatu masyarakat adanya alat perekat berupa suatu gerakan atau perkumpulan yang diorganisir dengan baik dengan normanorma yang jelas. Pernyataan ini perlu dilengkapi dengan pola pembinaan yang jelas dan sistimatis, salah satu gerakan dan kekuatan yang telah melakukan pembinaan di masyarakat ditelaah adalah Jamaah Tabligh.

Jamaah Tabligh dalam melakukan pembinaan terhadap masyarakat telah mampu menunjukkan hasil dari pembinaan itu, dari hasil pembinaan itu akan dapat dijadikan modal sosial dalam mengembangkan masyarakat Islam khususnya di kota Palu. Salah bentuk pembinaan adalah syuro atau musyawarah, melalui musyawarah ini telah menjadi suatu modal sosial yang dapat mengembangkan masyarakat. Musyawarah yang dik\lakukan dengan model berjenjang. Jenjang musyawarah yang dimaksud adalah mulai dari jenjang mahalah, halaqah, dan markas. Ketiga jenjang ini telah mampu menyatukan pikir, satu kerja, satu hati dan satu kasih sayang antar mahala, antar halaqah dan markas. Kesatuan inilah yang merupakan modal sangat kuat yang menjadi modal sosial.

\section{Daftar Pustaka}

Depertemen Agama RI, Al-Qur'an dan Terjemahnya, Solo: PT. Tiga Serangkai Mandiri, 2008

Fransis Fukuyama. Trust: The social Virtues and the Creation of Prosperty. New York: The Free Press

Franz Magis Suseno. 2001. Etika Jawa Sebuah Analisa Falsafi Tentang Kebijaksanaan Hidup Jawa. Jakarta: PT. Gramedia Utama

Gazalba, Sidi. 1989. Masjid Pusat Ibadah dan Kebudayaan Islam. Jakarta: Pustaka Antara 
Haidlor Ali Ahmad. 2011. Antara Harmoni dan Konflik Umat Beragama di Kabupaten Kediri. Dalam Harmoni

Hari Poerwanto. 2000. Kebudayaan dan Lingkungan dalam Perspektif Antroplogi. Yogyakarta: Pustaka Pelajar

Hans Kung. 1998. Sebuah Model dialog kristen-Islam" dalam jurnal Paramadina. Jakarta: Paramadina

Imam Suprayogo. 2015 Memahami Realitas Sosial Keagamaan, Jakarta: Kementerian Agama RI, Badan Litbang dan Diklat Puslitbang Kehidupan Keagamaan.

J. S, Coleman, Fondation. 1989. of Social Theory. Cambridge: Harvad Uneversity Press

Latifatul Azizah el Mahdi. 2009. Dialog Aksi Antar Umat Bergama: Strategi Membangun Perdamaian dan Kesejahteraan Bangsa: dalam Harmoni. Volume VIII nomor 30

LPM UIN Malang. 2011. Pedoman Pelaksanaan Pengabdian Kepada Masyarakat Tematik Posdaya Berbasis Masjid. Malang: PT Citra Kharisma Bunda

M. Ishak Shahab An Naddhar. 2011. Khuruj Fi Sabilillah. Bandung: Pustaka Ramdhan.

Muhammad M. Basyuni. 2007. Kebijakan dan Strategi Kerukunan Umat Beragama, Jakarta: Balitbang dan Diklat Depag RI

Mukti Ali. 1994. Dialong dan Kerjasama Agama dalam Menanggulangi Kemiskinan" dalam Weinata Sairin (ed), Dialong Antar Umat Beragama: Membangun Pilar-pilar Keindonesiaan yang Kukuh. Jakarta: BPK Gunung Mulia

Malcom Knowles. 1979. Modern Parctice of edult education from Paedagogy to Andragogy. Chicago: Fiolet Publishing Company

Rolf Zimmermann. 1984. Emancipation and Rationality: foundational Problems in the Theories of Max and Habermas: Dalam Ratio, XXXVI

Robert D Putham. 1995 . Bowling alone. America's declining Social Capital. Jurnal: of Democrary 